\title{
Marker-assisted Foreground Selection for Identification of Salt Tolerant Rice Genotypes
}

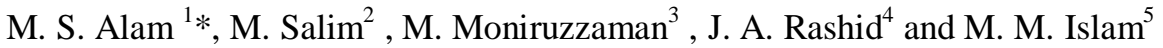 \\ ${ }^{1}$ Regional Agricultural Research Station, BARI, Akbarpur, Moulvibazar, Bangladesh \\ ${ }^{2}$ Hill Agricultural Research Station, BARI, Khagrachari, Bangladesh \\ ${ }^{3}$ Bangladesh Jute Research Institute (BJRI), Manikgonj, Dhaka, Bangladesh \\ ${ }^{4}$ MATEX Bangladesh Ltd. Dhaka, Bangladesh \\ ${ }^{5}$ Biotechnology Div., Bangladesh Institute of Nuclear Agriculture, Mymensingh, Bangladesh \\ *Corresponding author and Email: asarowar04bau@ gmail.com
}

Received: 20 May $2012 \quad$ Accepted: 15 November 2012

\begin{abstract}
Marker Assisted Selection (MAS) technique was used to develop salt tolerant rice genotypes using molecular markers during June 2009 to November 2010 in the experimental field and Biotechnology Laboratory of Plant Breeding Division, Bangladesh Institute of Nuclear Agriculture (BINA), Mymensingh. FL-378 was identified as donor or male parent for saltol QTL and Binadhan-7 as recurrent or recipient parent which had high yield with short life cycle. Crossing was done between them and $10 \mathrm{~F}_{1}$ seeds were produced. PCR bands from all the $10 \mathrm{~F}_{1}$ plants were scored as " $\mathrm{H}$ " represented heterozygous alleles for donor and recipient parent. Backcrossing was done to produce 105 $\mathrm{BC}_{1} \mathrm{~F}_{1}$ seedlings. Foreground selection was performed with $72 \mathrm{BC}_{1} \mathrm{~F}_{1}$ plants with a tightly linked salt tolerance marker RM21. Out of 72 plants, 33 plants were selected for RM21 showing ' $\mathrm{H}$ ' scores. The selected segregants were subjected to further recombinant and background selections at $\mathrm{BC}_{1} \mathrm{~F}_{1}$ generation. These selected genotypess could be used for further foreground, recombinant and background selections with appropriate markers upto $\mathrm{BC}_{3}$ generation for the development of salt tolerant rice genotypes.
\end{abstract}

\section{Keywords: Marker-Assisted Selection (MAS), foreground selection, salinity, SSR marker}

\section{Introduction}

Salinity is one of the major obstacles to increasing production in rice growing areas worldwide. Therefore, development of salt tolerant varieties has been considered as one of the strategies to increase rice production in salinity prone coastal areas.

Salt stress is a major constraint to cereal production worldwide. In Bangladesh, out of 2.8 million hectares of the coastal area, around 1.0 million ha has become saline due to heavy withdrawal of surface and groundwater for irrigation and intrusion of seawater. The total coastal saline area covers one third of the 9 million hectares of total cultivated area in Bangladesh (ABSPII, 2006). Agriculture is a major sector of Bangladesh economy and the coastal area of Bangladesh is very fertile for growing rice. Increase in salinity intrusion and increase in soil salinity will have serious negative impacts on agriculture. The food production does not seem to have a better future in the event of a climate change. In Bangladesh, rice production may fall by $10 \%$ and wheat by $30 \%$ by 2050 (IPCC, 2007). 
SSR or microsatellite markers are proved to be ideal for making genetic maps (Islam, 2004; Niones, 2004), assisting selection (Bhuiyan, 2005) and studying genetic diversity in crop germplasm. Microsatellite marker analysis is promising to identify major gene locus for salt tolerance that can be helpful for plant breeders to develop new cultivars. Currently, SSRs are predominantly being used to map and introgress agronomically important Quantitative Trait Loci (QTLs) into popular varieties using MarkerAssisted Backcrossing (MABC). However, their use is still limited due to lack of sufficient polymorphism particularly within related genotypes, labor requirements and cost of application. In addition, SSR markers have a low potential for multiplexing and require lengthy periods of time to genotype many markers as during the initial background selection in the marker-assisted backcrossing protocol (Thomson et al., 2010).

Thus, the objective of this study was to identify salt tolerant rice genotypes using molecular markers and to introgress saltol gene into Binadhan-7 with marker assisted selection technique.

\section{Materials and Methods}

\subsection{Field experiment}

Salt tolerant genotype FL-378 was selected as donor parent and Binadhan-7 was selected as recurrent or recipient parent. The experiment was conducted on the plastic pot (10L bucket) and pans designed by IRRI. The plants were labeled with pot labeler.

\subsubsection{Location and time}

For the identification of salt tolerant rice genotypes with marker assisted backcrossing (MABC) technique, the experiment was conducted during the period from July 2009 to November 2010 in the experimental field and Biotechnology Laboratory of Plant Breeding Division, Bangladesh Institute of Nuclear Agriculture (BINA), Mymensingh.

\subsubsection{Plant materials}

Binadhan-7 was an early and high yielding salt susceptible mutant variety which was crossed with FL 378 which was an advanced salt tolerant line from IRRI. Binadhan-7 was the recurrent parent and FL 378 was the non-recurrent donor line. Seeds of selected $F_{1}$ lines were grown in the pot. Then $\mathrm{F}_{1}$ plants were crossed with Binadhan7 as a principle of backcrossing and $150 \mathrm{BC}_{1} \mathrm{~F}_{1}$ seeds were developed. Among these seeds, 105 seeds were germinated in the experimental field in the next season. Among these 105 seedlings 72 seedlings were selected to collect the leaf samples to apply foreground selection using SSR markers.

\subsection{3. $F_{1}$ plant production}

Hybridization was carried out between Binadhan-7 and FL-378 . Binadhan-7 was used as female parent while FL-378 as male parent in the hybridization scheme. Three sets parental lines were seeded at an interval of 14 days starting from July 5, 2009. Twenty- one days old seedlings were transplanted in the hybridization block.

\section{a. Cultural management of hybridization nursery}

Complete N-P-K-S fertilizers were applied at recommended doses. Urea were applied both at 20 and 40 DAT. Weeding and rouging were done carefully. Other cultural management practices were carried out as required.

\subsubsection{Production of backcross seeds}

\section{a. $B C_{1} F_{1}$ seeds Production}

For producing $\mathrm{BC}_{1} \mathrm{~F}_{1}$ seeds, $\mathrm{F}_{1}$ seeds were seeded on 15 February, 2010. Four sets of Binadhan-7 were seeded for synchronization of flowering with $\mathrm{F}_{1}$ plants for producing $\mathrm{BC}_{1} \mathrm{~F}_{1}$ seeds. They were sown at an interval of 7 days starting from February 1, 2010. 


\section{b. Soaking, seeding and transplanting of $B C_{1} F_{1}$ seeds}

The total number of $\mathrm{BC}_{1} \mathrm{~F}_{1}$ seeds produced was 150. In order to handle all the selection approaches and also for introgression of saltol gene by backcrossing all the $\mathrm{BC}_{1} \mathrm{~F}_{1}$ seeds were used.

\subsubsection{Raising of backcross plants}

The mature backcrossed seeds were collected 21 days after dusting. The seeds were dried in the oven at $50^{\circ} \mathrm{C}$ temperature for 72 hours for breaking dormancy. Seeds were seeded and then transplanted 21 days after seeding in the prepared pots (Fig. 2).

\subsubsection{Collection of leaf sample for DNA extraction}

Young vigorously growing fresh leaf samples from these seedlings were collected from 25 day old seedlings to extract genomic DNA. Initially, healthy portion of the youngest leaves of the tiller were cut apart with sterilized scissors and washed in distilled water and ethanol $(70 \%)$ and dried on fresh tissue paper to remove spore of microorganisms and any other source of foreign DNA. The collected leaf samples were then kept in polythene bags, avoiding any damage of the leaf tissues the bags were placed in an ice box to carry. Finally, the samples were stored in $-80^{\circ} \mathrm{C}$ freezer with marking.

\subsection{Genomic DNA extraction}

DNA was extracted from the leaves of each genotype using the Cetyl Trimethyl Ammonium Bromide (CTAB) mini-prep method at Biotechnology Lab., Bangladesh Institute of Nuclear Agriculture (BINA), Mymensingh. The simplified mini scale procedure for DNA isolation in PCR analysis developed at IRRI was followed. The quality of the isolated DNA in the protocol was sufficient for PCR analysis (Zheng et al., 1995). The following steps were followed in PCR-based DNA marker analysis.

\subsection{PCR analysis for microsatellite (SSR) markers}

\subsubsection{Polymorphism survey for primer selection}

Polymorphism survey of parent plants were carried out using 30 microsatellite markers. Out of these SSR primers, one primer (RM21) showed clear polymorphisms which were used in genotyping for the foreground selection of the 72 $\mathrm{BC}_{1} \mathrm{~F}_{1}$ plants. The details of the primer are given in Table 1.

\subsubsection{Polymerase chain reaction (PCR)}

The PCR cocktail including DNA had total volume of $14.75 \mu \mathrm{l} /$ reaction based on rice protocol, was placed in the PCR tubes and run in the DNA thermal cycler. The PCR reactions were: initial denaturation at $94^{\circ} \mathrm{C}$ for 5 minutes, then final denaturation at $94^{\circ} \mathrm{C}$ for 1 minute and annealing at $55^{\circ} \mathrm{C}$ for one minute. Polymerization was carried out at $72^{\circ} \mathrm{C}$ for 2 minutes to complete a cycle and cycle was repeated for 34 times. The final extension was at $72^{\circ} \mathrm{C}$ for 7 minutes. After PCR, products were mixed with $3 \mu \mathrm{l}$ of $2 \mathrm{X}$ gel loading dye. Polymorphisms in the PCR products were detected by ethidium bromide staining after electrophoresis on $1.5 \%$ agarose gel using UV transilluminator.

\subsubsection{Components of PCR cocktail (for 74 reactions) for foreground selection}

The following components were used to prepare PCR cocktail (Table 2). The total volume of PCR cocktail for this study was $12.75 \mu 1$ per sample.

\subsection{Selection strategy for marker assisted selection (MAS)}

The use of DNA markers in backcrossing greatly increases the efficiency of selection. Three general levels of marker-assisted backcrossing (MABC) were described (Holland 2004). In the first level, markers can be used in combination 
with or to replace screening for the target gene or QTL. This is referred to as 'foreground selection' (Hospital and Charcosset, 1997). This may be particularly useful for traits that have laborious or time-consuming phenotypic screening procedures. It can also be used to select for reproductive-stage traits in the seedling stage, allowing the best plants to be identified for backcrossing. Furthermore, recessive alleles can be selected, which is difficult to do using conventional methods (Fig. 1).

\subsection{Band scoring of $F_{1}$ plants}

DNA samples were collected from $10 F_{1}$ plants and PCR was carried out using one SSR marker RM21. PCR bands from all the $10 \mathrm{~F}_{1}$ plants were scored as " $H$ ". Score " $\mathrm{H}$ " represented heterozygous alleles for donor and recipient parent (Fig. 3).

\subsection{Allele scoring for foreground selection}

The size (in nucleotide base pairs) of the most intensely amplified band for each microsatellite marker was determined based on its migration relative to a molecular weight size marker $(1 \mathrm{~kb}+$ DNA ladder) with the help of Alpha Ease 4.0 software. The band having same level of Binadhan-7 was scored as 'A' which indicated the homozygous allele of the recipient parent for the particular SSR marker. Again, the band having same level of FL-378 was scored as 'B' which indicated the homozygous allele of the donor parent for the particular SSR marker. However, heterozygous alleles were scored as ' $\mathrm{H}$ ' having both the bands of two parents. Score ' $\mathrm{N}$ ' indicated the absence of band. Importantly, heterozygous alleles always had the extra bands in most cases with bigger size.

\section{Results and Discussion}

\subsection{Introgression of the saltol gene into Binadhan-7 using MAS}

The main aim of this study was to introgress the saltol gene into Binadhan-7 using a marker assisted backcrossing approach in order to maximize the recovery of all of the desirable characteristics of the recurrent parent. During this process, further selection strategies associated with marker-assisted backcross breeding were done. The results of these selection strategies were as follows:

\subsection{Confirmation of $F_{1}$ plants}

DNA samples were collected from $10 \mathrm{~F}_{1}$ plants and PCR was carried out using one SSR marker RM21. PCR bands from all the $10 \mathrm{~F}_{1}$ plants were scored as " $H$ ". Score " $H$ " represented heterozygous alleles for donor and recipient parent. Fig. 1 shows the gel picture of $F_{1}$ confirmation using a SSR marker RM21. All the $\mathrm{F}_{1} \mathrm{~s}$ were confirmed as true $\mathrm{F}_{1}$ (Fig. 3 ).

\subsection{Parental Survey}

A primer survey is an important prerequisite before starting marker-assisted backcross breeding. A comprehensive primer survey is required for successful foreground, recombinant and background selection. Polymorphic markers are essential for a MABC scheme. A marker which is monomorphic bears no value in selection work because this type of marker can not distinguish the two parental genotypes viz. Binadhan-7, the recurrent or recipient parent and FL-378, the donor parent of the MABC program. A total of 30 SSR primers were surveyed for finding out polymorphic markers and among them one primer was found as polymorphic.

\subsection{Foreground selection at $B C_{1} F_{1}$ generation}

A total of $150 \mathrm{BC}_{1} \mathrm{~F}_{1}$ seeds were produced from $10 \mathrm{~F}_{1}$ plants (Table 3) and 105 plants were survived in the main fields. Foreground selection was performed on 72 plants. Foreground selection was carried out using a tightly linked salt tolerance marker RM21. The marker produced very conspicuous bands (Fig. 4, 5 \& 6) and it was possible to identify the genetic constitution of the saltol QTLs very easily using agarose gel electrophoresis. 


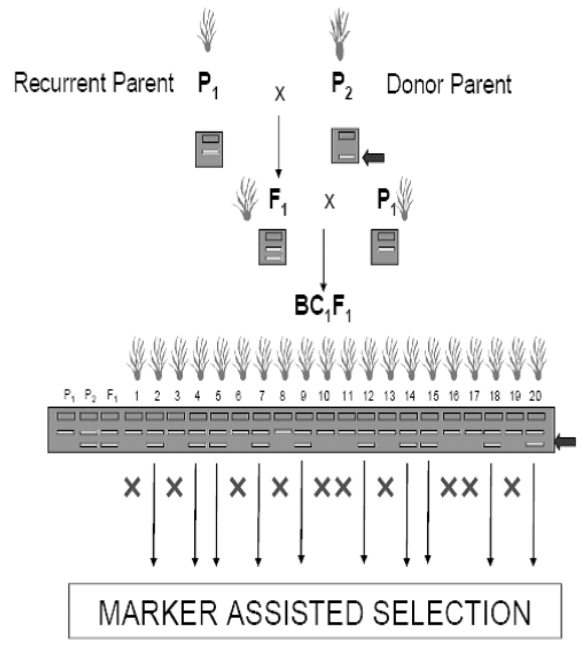

Fig. 1. Marker-assisted foreground selection

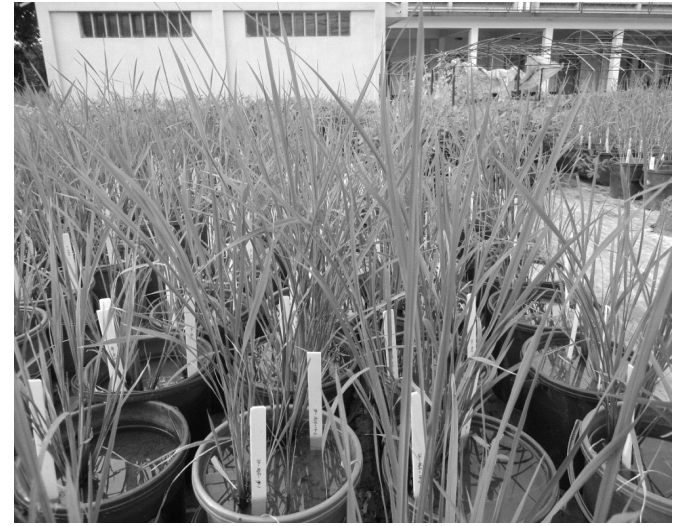

Fig. 2. $\mathrm{BC}_{1} \mathrm{~F}_{1}$ generation in the field

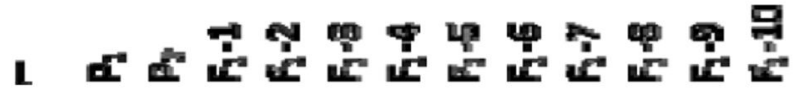

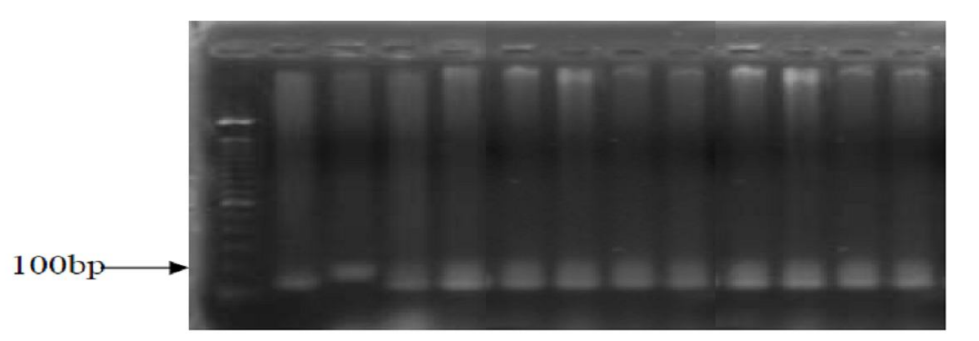

Fig. 3. Complete view of gel showing confirmation of $F_{1} s$ of Binadhan-7 x FL-378 using SSR marker RM 21

Table 1. Summary of microsatellite (SSR) marker used for $\mathrm{BC}_{1} \mathrm{~F}_{1}$ DNA study

\begin{tabular}{ccccccc}
\hline $\begin{array}{c}\text { Primer } \\
\text { name }\end{array}$ & $\begin{array}{c}\text { Expected } \\
\text { PCR } \\
\text { product } \\
\text { size (bp) }\end{array}$ & $\begin{array}{c}\text { Chrom. } \\
\text { position }\end{array}$ & $\begin{array}{c}\text { Repeat } \\
\text { Motif }\end{array}$ & Primer sequence & $\begin{array}{c}\text { Annealing } \\
\text { Temp. } \\
\left({ }^{\circ} \mathrm{C}\right)\end{array}$ \\
\hline RM 21 & 105 & 8 & (TC)18 & $\begin{array}{c}\text { For. } \\
\text { Rev. }\end{array}$ & $\begin{array}{c}\text { ACAGTATTCCGTAGGCACGG } \\
\text { GCTCCATGAGGGTGGTAGAG }\end{array}$ & 55 \\
\hline
\end{tabular}


Table 2. Components of PCR cocktail (for 74 reactions) for foreground selection

\begin{tabular}{cccc}
\hline SL & Component & Quantity (for single reaction) & Total \\
\hline 1 & 10X Buffer & $1.5 \mu \mathrm{l}$ & $111.0 \mu \mathrm{l}$ \\
2 & dNTPs & $0.75 \mu \mathrm{l}$ & $55.5 \mu \mathrm{l}$ \\
3 & Primer forward & $1.0 \mu \mathrm{l}$ & $74.0 \mu \mathrm{l}$ \\
4 & Primer reverse & $1.0 \mu \mathrm{l}$ & $74.0 \mu \mathrm{l}$ \\
5 & Taq polymerase & $0.25 \mu \mathrm{l}$ & $18.5 \mu \mathrm{l}$ \\
6 & $\mathrm{ddH}_{2} \mathrm{O}$ & $8.25 \mu \mathrm{l}$ & $610.5 \mu \mathrm{l}$ \\
\hline & Total volume & $1554.0 \mu \mathrm{l}$ \\
\hline
\end{tabular}

Table 3. List of $\mathrm{BC}_{1} \mathrm{~F}_{1}$ seeds produced

\begin{tabular}{cccc}
\hline SN & $\mathrm{F}_{1}$ & Recurrent parent & $\mathrm{BC}_{1} \mathrm{~F}_{1}$ Seeds \\
\hline 1 & 1 & X Binadhan-7 & 20 \\
2 & 2 & X Binadhan-7 & 14 \\
3 & 3 & X Binadhan-7 & 19 \\
4 & 4 & X Binadhan-7 & 9 \\
5 & 5 & X Binadhan-7 & 17 \\
6 & 6 & X Binadhan-7 & 15 \\
7 & 7 & X Binadhan-7 & 8 \\
8 & 8 & X Binadhan-7 & 11 \\
9 & 9 & X Binadhan-7 & 16 \\
10 & 10 & X Binadhan-7 & 21 \\
\hline & Total & & 150 \\
\hline
\end{tabular}

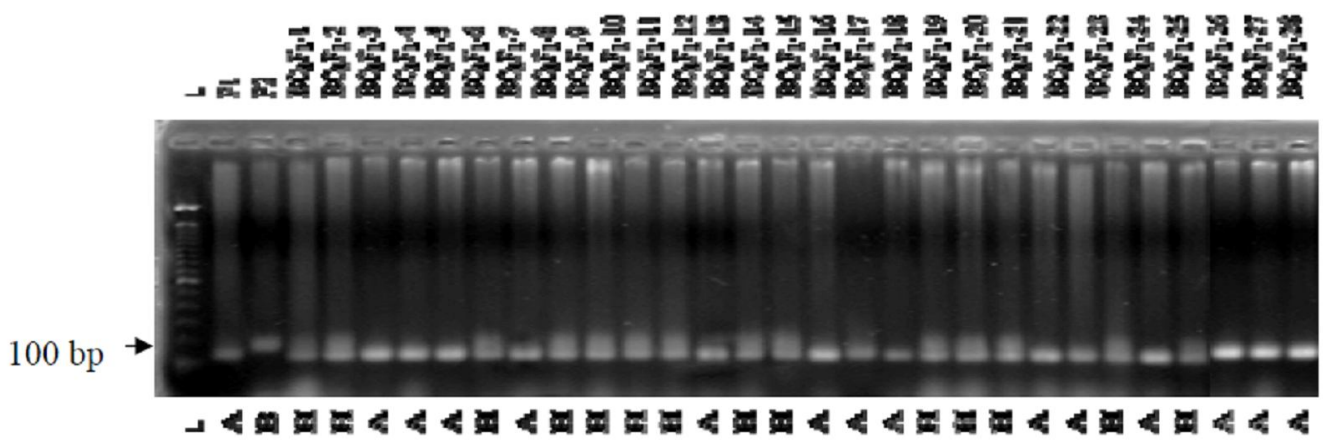

Fig. 4. Gel picture of the foreground selection of $\mathrm{BC}_{1} \mathrm{~F}_{1}$ population (1-28) with tightly linked salt tolerance marker RM21 


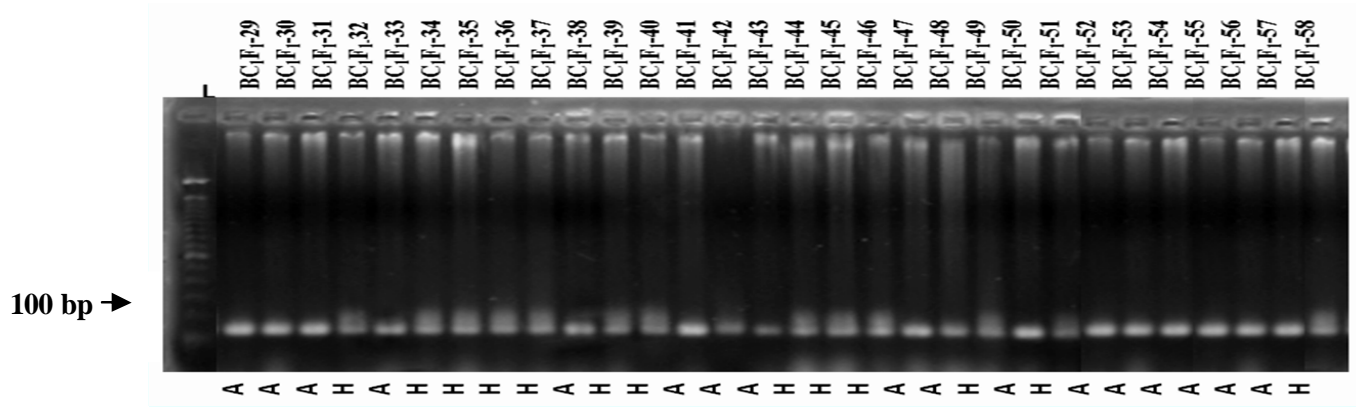

Fig. 5. Gel picture of the foreground selection of $\mathrm{BC}_{1} \mathrm{~F}_{1}$ population (29-58) with tightly linked salt tolerance marker RM21

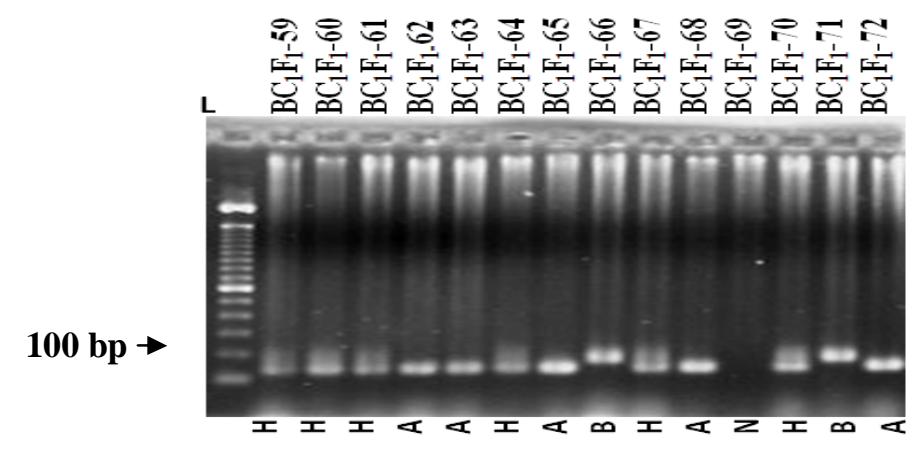

Fig. 6. Gel picture of the foreground selection of $\mathrm{BC}_{1} \mathrm{~F}_{1}$ population (59-72) with tightly linked salt tolerance marker RM21

\subsection{Foreground selection at $B C_{1} F_{1}$ generation with tightly linked marker RM21}

Out of 72 plants, 33 plants were found showing the locus for tightly linked marker as heterozygous state (score $\mathrm{H}$ ), 36 plants were found with the locus fixed for recipient allele (susceptible allele) (score A), 2 plants were found with the locus fixed for donor allele (resistant allele) (score B) and one score ' $\mathrm{N}$ ' indicated the absence of band. The two plants with B score were found may be due to accidental failure of backcrossing. The 33 plants with the ' $\mathrm{H}$ ' score for the tightly linked marker
RM21 were subjected for recombinant selection. It was expected that those 33 individuals possessed the salt tolerant allele. So, these segregants were selected and promoted for further selection.

The results were similar to the study of Neeraja et al. (2007) where foreground selection was performed with marker assisted backcrossing of rice for introgression of promising gene. Iftekharuddaula (2009) found similar results in his study on foreground selection in $\mathrm{BC}_{1} \mathrm{~F}_{1}$ populations with marker assisted backcrossing to popular rice variety BR11. 


\section{Conclusions}

Based on the foreground selection with a tightly linked salt tolerance marker RM21, we selected 33 plants showing ' $\mathrm{H}$ ' scores were selected. The selected segregants were subjected to further recombinant and background selections in $\mathrm{BC}_{1} \mathrm{~F}_{1}$ generation. And further foreground, recombinant and background selections will be done with appropriate markers up to $\mathrm{BC}_{3}$ or more for the development of salt tolerant rice lines and will be reported elsewhere.

\section{References}

ABSPII. 2006. Drought tolerant rice and salinity tolerance rice. Agricultural Biotechnology Support Project II- South Asia, 26 p.

Bhuiyan, M. A. R. 2005. Efficiency in evaluating salt tolerance in rice using phenotypic and marker assisted selection. M.S. Thesis, Department of Genetics and Plant Breeding, Bangladesh Agricultural University, Mymensingh, Bangladesh, 96 p.

Holland, J. B. 2004. Implementation of molecular markers for quantitative traits in breeding programs-challenges and opportunities. Proc. 4th Int. Crop Sci. Congress., Brisbane, Australia, 26 September-1 October, 2004.

Hospital, F. and Charcosset A., 1997. Markerassisted introgression of quantitative trait loci. Genetics. 147:1469-1485.

Iftekharuddaula, K. M. 2009. Comparison of new selection strategies of markerassisted backcrossing for a submergence tolerant gene in rice. $P h$. D. dissertation.
Bangladesh agricultural University, Mymensingh. 75-91 p.

IPCC, 2007. Climate change in Asia too alarming to contemplate. Intergovernmental Panel on Climatic change, $85 \mathrm{p}$.

Islam, M. M. 2004. Mapping salinity tolerance genes in rice (Oryza sativa L.) at reproductive stage. $P h$. D. Dissertation. University of the Philippines Los Baños, College, Laguna, Philippines, 149 p.

Neeraja, C. N., Maghirang-Rodriguez, R., Pamplona, A., Heuer, S., Collard, B. C. Y., Septiningsih, E. M., Vergara, G., Sanchez, D., Xu, K., Ismail, A. M., Mackill, D. J. 2007. A marker-assisted backcross approach for developing submergence-tolerant rice cultivars. Theorical Application of Genetics, 115:767-776.

Niones, J. M. 2004. Fine mapping of the salinity tolerance gene on chromosome 1 of rice (Oryza sativa L.) using near-isogenic lines. M. S. dissertation. University of the Philippines Los Baños, College, Laguna, Philippines, $78 \mathrm{p}$.

Thomson, M. J., Ismail, A. M., McCouch, S, R., Mackill, M. J. 2010. Marker Assisted Breeding (Chap. 20), Abiotic Stress Adaptation in Plants: Physiological, Molecular and Genomic Foundation, 451$469 \mathrm{pp}$.

Zheng, K., Huang, N., Bennet, J. and Khush, G.S. 1995. PCR-based marker assisted selection in rice breeding. International Rice Research Institute, Los Baños, Laguna. Philippines, 24 p. 